\title{
Kebiasaan makan pada anak gangguan spektrum autisme
}

\author{
${ }^{1}$ Elfriani M. Onibala \\ ${ }^{2}$ Anita E. Dundu \\ ${ }^{2}$ Lisbeth F. J. Kandou
}

\author{
${ }^{1}$ Kandidat Skripsi Fakultas Kedokteran Universitas Sam Ratulangi Manado \\ ${ }^{2}$ Bagian Psikiatri RSUP Prof. Dr. R. D. Kandou Manado \\ Email: elfriani_onibala@yahoo.com
}

\begin{abstract}
Autism or Autistic Spectrum Disorder (ASD) is a developmental disorder which is marked as disorders in communication and social interaction, and repeated behavior. The causes of autism are not clear yet, however, genetic, environmental, and immunological factors might have some roles in the occurence of autism. Autistic children usually have different eating habits, such as eating the same kind of food for a pretty long time. Autistic children should be given gluten free, casein free, and additive substance free diets since this can improve their hyperactivity. This study aimed to obtain the eating habits of autistic children in several schools in Manado. There were 33 respondents who filled questionnaires about the eating habbit of their autistic children. The results showed that there were 10 children (30.1\%) who frequently consumed gluten; 18 children (54.6\%) who rarely consumed gluten; and 5 children (13.2\%) who did not consume gluten. About casein consumption, there were 10 children (30.1\%) who frequently consumed casein, 12 children $(36.4 \%)$ who rarely consumed casein, and 11 children (33.4\%) who did not consume casein. About additive substance consumption, there were 6 children (18.2\%) who frequently consumed additive substances; 17 children (51.6\%) who rarely consumed additive substances; and 10 children (30.1\%) who did not consume these additive substances.
\end{abstract}

Keywords: autism, eating habit

\begin{abstract}
Abstrak: Autisme pada anak atau Autistic Spectrum Disorder (ASD) merupakan gangguan perkembangan yang ditandai dengan gangguan komunikasi, gangguan interaksi sosial, dan perilaku berulang. Penyebab autisme belum diketahui pasti. Diduga faktor genetik, lingkungan, dan sistem imun berperan pada terjadinya gangguan ini. Anak autis biasanya memiliki kebiasaan makan yang berbeda, seperti sering memakan jenis makanan yang sama secara berulang-ulang dalam waktu yang cukup lama. Kebiasaan makan ini dapat berpengaruh pada perbaikan perilaku anak autis. Pada anak autisme biasanya diterapkan makanan bebas gluten, kasein, dan zat aditif karena dapat membantu perbaikan hiperaktivitas. Penelitian ini bertujuan untuk mengetahui kebiasaan makan pada anak autis di beberapa Sekolah Luar Biasa di Manado. Terdapat 33 responden yang mengisi kuesioner tentang kebiasaan makan anak autis. Hasil penelitian mendapatkan 10 anak (30,1\%) sering mengonsumsi gluten, 18 anak $(54,6 \%)$ jarang mengonsumsi gluten, dan 5 anak $(13,2 \%)$ tidak mengonsumsi gluten. Mengenai konsumsi kasein dari 33 responden terdapat 10 anak $(30,1 \%)$ sering mengonsumsi kasein, 12 anak (36,4\%) jarang mengonsumsi kasein, dan 11 anak (33,4\%) tidak mengonsumsi kasein. Mengenai bahan aditif, 6 anak (18,2\%) yang sering mengonsumsi zat aditif, 17 anak (51,6\%) jarang mengonsumsi zat aditif, dan 10 anak (30,1\%) tidak mengonsumsi zat aditif.
\end{abstract}

Kata kunci: autisme, kebiasaan makan 
Definisi autis pada anak atau Autistic Spectrum Disorder (ASD) merupakan gangguan perkembangan yang ditandai dengan gangguan komunikasi, gangguan interaksi social, dan perilaku berulang. Penyebab autisme belum diketahui secara pasti. Faktor genetik, lingkungan dan faktor imunologi mungkin berperan terhadap terjadinya autisme. Autisme dapat diderita oleh anak siapapun tanpa melihat status sosial dan tingkat ekonomi keluarga. ${ }^{1}$

Data United Nations Education, Scientific and Cultural Organization (UNESCO) tahun 2011 mencatat terdapat sekitar 35 juta penyandang autis di dunia. Hal ini berarti rata-rata 6 dari 1000 orang di dunia menyandang autis. UNESCO melaporkan prevalensi autisme di Hongkong sebesar 1,68 per 1000 untuk anak di bawah usia 15 tahun. Hasil penelitian yang dilakukan Centers of Disease Control and Prevention (CDC) tahun 2008 mendapatkan prevalensi anak spektrum autisme ialah 1:80. Penelitian CDC selanjutnya menunjukkan adanya peningkatan prevalensi spektrum autisme, dimana tahun 2013 prevalensi penyandang spektrum autisme di Amerika Serikat 1:50. Di Indonesia belum ada data terbaru mengenai jumlah anak spekrum autisme. Data terakhir di Indonesia pada tahun 2004 tercatat sebanyak 475 ribu penderita. Hasil tersebut dikemukakan Menteri Kesehatan Siti Fadila Supari dalam pembukaan rangkaian Expo Peduli Autisme yang diselenggarakan tahun 2008. Sampai saat ini penulis belum mendapatkan data terbaru prevalensi anak autisme di Indonesia. ${ }^{1-4}$

Anak autis biasanya memiliki kebiasaan makan yang berbeda, seperti sering memakan jenis makanan yang sama secara berulang-ulang dalam waktu yang cukup lama. Anak autis juga mengonsumsi makanan yang relatif terbatas. Kebiasaan makan pada anak autis dapat berpengaruh pada perbaikan perilakunya. Pada anak autis biasanya diterapkan makanan bebas gluten, kasein, dan zat aditif karena dapat membantu perbaikan hiperaktivitas. Beberapa penelitian mendapatkan bahwa penggunaan makanan yang mengandung gluten, kasein dan, zat aditif dapat meningkatkan gangguan perilaku anak autisme. ${ }^{5,6}$

Penelitian yang dilakukan oleh Latifa tahun 2004 di Bogor mendapatkan hasil sebanyak 68,24\% anak autis menunjukkan adanya perbaikan perilaku terutama pada tingkat hiperaktivitas setelah diberikan terapi diet bebas gluten dan bebas kasein. Penelitian lain yang dilakukan Destiani tahun 2012 di Bandung menemukan bahwa $85 \%$ orangtua tidak menerapkan terapi bebas gluten, kasein, dan zat aditif berdampak pada terjadinya gangguan perilaku anak mereka. Tidak terdapat kekurangan nutrisi pada anak yang menerapkan pola makan ini. ${ }^{6-8}$

Penelitian yang dilakukan oleh Yayasan Tali Kasih terdapat 32 orang ibu yang memiliki anak dengan gangguan spektrum autisme bermasalah karena anak mereka mengalami kesulitan dalam menerima makanan dimana terjadi ketidakcocokan terhadap makanan yang dikonsumsi anak-anak tersebut. Hal ini menyebabkan terjadinya gangguan pencernaan, alergi, dan bahkan berdampak pada perilaku anak dengan gangguan spektrum autisme. Anak menjadi lebih agresif, cengeng, dan cepat marah, sehingga diperlukan perhatian ibu dalam menerapkan kebiasaan makan yang baik terhadap anak autis. ${ }^{9}$

\section{METODE PENELITIAN \\ Penelitian kuantitatif}

Jenis penelitian ini ialah deskriptif kuantitatif dengan desain potong lintang menggunakan kuesioner untuk mengetahui gambaran pola makan anak-anak yang terdiagnosis gangguan spektrum autisme.

\section{Penelitian kualitatif}

Penelitian ini dilakukan setelah penelitian kuantitatif selesai. Jenis penelitian ini ialah deskriptif kualitatif menggunakan studi kasus dengan metode wawancara mendalam pada 2 orang tua atau pengasuh mengenai pola makan pada anak gangguan spektrum autisme. 


\section{HASIL PENELITIAN}

Penelitian tentang kebiasaan makan pada anak gangguan spektrum autisme dilakukan di SLB Khusus Autis Permata Hati, SLB Khusus Autis Hizkia, SLB AGCA Center Manado, SLB GMIM Nazareth Tuminting, SLB B/C Kristen Emmanuel, SLB A Bartemeus, SLB YPAC Manado, SLB Tuna Grahita St. Anna, Autism Center Manado, Sentra Pendidikan Anak Berkebutuhan Khusus Amadeus dari bulan November 2015 sampai bulan Januari 2016 dan didapatkan 64 anak dengan gangguan spektrum autisme melalui skrining awal. Responden yang ikut berpartisipasi mengikuti pengisian kuesioner tentang pola makan autisme sebanyak 33 orang. Wawancara mendalam dilakukan terhadap 2 responden yang bersedia untuk diwawancarai.

Dari 33 anak autisme, yang terbanyak ialah pada usia 8 dan 12 tahun masingmasing sebanyak 4 anak (12,1\%). Tidak terdapat anak autis yang berusia $\leq 5$ tahun (Tabel 1).

Tabel 1. Distribusi anak autism berdasarkan usia

\begin{tabular}{ccc}
\hline & \multicolumn{2}{l}{ Jumlah anak autis } \\
Usia & $\mathbf{N}$ & $\mathbf{\%}$ \\
\hline 3 & 0 & 0 \\
4 & 0 & 0 \\
5 & 0 & 0 \\
6 & 2 & 6,06 \\
7 & 3 & 9,09 \\
8 & 4 & 12,1 \\
9 & 3 & 9,09 \\
10 & 3 & 9,09 \\
11 & 2 & 6,06 \\
12 & 4 & 12,1 \\
13 & 2 & 6,06 \\
14 & 2 & 6,06 \\
15 & 3 & 9,09 \\
16 & 2 & 6,06 \\
17 & 3 & 9,09 \\
\hline
\end{tabular}

Pada penelitian ini didapatkan 26 anak laki-laki (78,8\%) dan 7 anak perempuan dari total 33 anak autis (Tabel 2).
Tabel 2. Distribusi anak autis berdasarkan jenis kelamin

\begin{tabular}{ccc}
\hline & \multicolumn{2}{c}{ Jumlah Anak } \\
Autisme \\
Jenis Kelamin & N & \% \\
\hline Laki-Laki & 26 & 78,8 \\
Perempuan & 7 & 21,2 \\
\hline
\end{tabular}

Hasil penelitian yang dilakukan terhadap 33 responden, terdapat 10 anak (30,1\%) sering mengonsumsi gluten, 18 anak $(54,6 \%)$ jarang mengonsumsi gluten, dan 5 anak (13,2\%) tidak mengonsumsi gluten. Mengenai konsumsi kasein, terdapat 10 anak (30,1\%) sering mengonsumsi kasein, 12 anak (36,4\%) jarang mengonsumsi kasein, dan 11 anak $(33,4 \%)$ tidak mengonsumsi kasein. Mengenai konsumsi zat aditif, terdapat 6 anak (18,2\%) sering mengonsumsi zat aditif, 17 anak (51,6\%) jarang mengonsumsi zat aditif, dan 10 anak (30,1\%) tidak mengonsumsi zat aditif (Tabel 3).

Tabel 3. Distribusi gambaran pola makan pada anak gangguan spektrum autism

\begin{tabular}{ccc}
\multicolumn{3}{c}{ Gluten } \\
\hline Jidak & Jarang & Sering \\
5 anak & 18 anak & 10 anak \\
$(15,2 \%)$ & $(54,6 \%)$ & $(30,1 \%)$ \\
\hline \multicolumn{3}{c}{ Kasein } \\
\hline 3 Jumlah sampel \\
\hline Jidak & Jarang & Sering \\
10 anak & 12 anak & 11 anak \\
$(30,1 \%)$ & (36,4 \%) & $(33,4 \%)$ \\
\hline \multicolumn{3}{c}{ Zat aditif } \\
\hline Jumlah sampel \\
\hline Tidak & Jarang & Sering \\
\hline anak & 17 anak & 6 anak \\
(30,1 \%) & (51,6 \%) & $(18,2 \%)$ \\
\hline
\end{tabular}

\section{Hasil penelitian kualitatif}

Penelitian kualitatif untuk sampel pertama dilakukan di rumah responden pertama bertempat di Sindulang 1 pada tanggal 20 januari 2016, pukul 20.00 WITA. Di dalam rumah terdapat kedua 
orang tua dan anak yang menderita gangguan spektrum autisme. Wawancara dilakukan di ruang tamu responden. Sampel kedua dilakukan di ruang kerja responden yang beralamat di jalan Diponegoro pada tanggal 21 januari 2016, pukul 12.30 WITA. Di dalam ruangan hanya terdapat responden sendiri. Penelitian kualitatif ini dilakukan terhadap 2 orang responden yang sebelumnya sudah bersedia mengisi kuesioner.

\section{Kasus pertama}

RL seorang anak laki-laki, 13 tahun, beragama Islam, bertempat tinggal di Sindulang 1 lingkungan 4, bersekolah di SLB AGCA Center Manado. RL tinggal bersama dengan orang tuanya dan 2 orang kakak perempuan; kedua kakaknya sekarang sudah bekerja. Orang tua RL ialah lulusan SMA. Ibu RL ialah seorang ibu rumah tangga dan ayah RL seorang wiraswasta. Saat mengandung sampai melahirkan RL, orangtua RL bertempat tinggal di Toli-toli. Pada saat ibu RL mengandung RL, ibu RL pernah terjatuh karena melompat dari mobil. Saat itu mobil yang ditumpangi mereka terundur ketika berada di tanjakan dari Manado ke Toli-toli sehingga ibu RL takut dan melompat keluar dari mobil. Mulai saat itu ketika mengandung RL, ibunya juga sering merasa takut saat mendengar ada kecelakaan.

RL dilahirkan di rumah sakit dan ditolong oleh bidan karena saat itu tidak ada dokter. RL lahir dengan keadaan yang sehat, kemudian RL diberikan imunisasi lengkap. Saat RL berusia 7 bulan, RL pernah mengalami demam sampai menggigil tetapi RL tidak dibawa ke dokter. Orang tua RL hanya mengobati RL dengan cara mengompres. Sejak RL lahir orang tua RL merasa RL biasa-biasa saja seperti bayi normal pada umumnya. Setelah RL berusia 1 tahun, mulai timbul kecurigaan dan rasa heran karena anak seusia RL seharusnya sudah dapat berbicara akan tetapi RL justru tidak bisa berbicara seperti menyebutkan mama dan papa. Saat itu RL sudah bisa berjalan, RL juga mempunyai kebiasaan menyendiri di dalam kamar serta melompat-lompat di tempat tidur dan tidak ingin diganggu.

Saat RL berusia 3 tahun orang tua RL melihat perkembangan RL yang tidak sama seperti anak lainnya yang bisa bermain layaknya anak pada umumnya. Orangtua RL yang bertempat tinggal di Toli-toli membawanya ke dokter untuk konsultasi tentang perilaku RL yang suka menyendiri dan sering melompat-lompat tanpa alasan. Pada saat dokter melakukan anamnesis orang tua RL memberitahu keluhan kepada dokter bahwa RL belum bisa bicara, selalu lompat-lompat ditempat tidur dan tidak fokus dalam berinteraksi; dokter mendiagnosis RL mengalami autis. Orang tua RL sempat bingung karena tidak mengerti apa yang di maksud dengan autis. Kemudian dokter menjelaskan kepada orang tua untuk membawa RL ke Manado agar supaya bisa diterapi.

Saat RL berusia 3 tahun, orangtuanya membawa RL ke Manado dan melakukan konsultasi dengan dokter di Manado. Dokter memberikan obat dan terapi perilaku kepada RL. Saat pertama kali dilakukan terapi, RL ditempatkan dalam ruangan yang hanya berdua dengan terapisnya. RL berteriak-teriak karena belum terbiasa dengan orang yang baru. Saat terapi berlangsung orangtua RL mulai mencari tahu tentang autis dengan cara sering berkonsultasi ke dokter dan membeli buku-buku tentang autis.

Saat RL berusia 5 tahun, RL senang menonton, cepat menghafal, bisa membaca, dan berbahasa inggris. Setelah RL berusia 7 tahun, RL dimasukan ke Sekolah Luar Biasa (SLB) di kota Manado karena RL mengalami autisme. Saat memasuki usia 13 tahun RL sudah menjadi malas dan tidak mau lagi membaca kecuali di sekolah. Guru RL mengatakan ke orang tuanya untuk mengajarkan RL menulis dan membaca di rumah, tetapi RL tidak mau.

Saat ini RL sangat suka berteriak dalam ruangan besar karena suaranya bisa berdenging kemudian RL tertawa. Sering kali RL ingin meminjam handphone kakaknya tetapi tidak diizinkan sehingga 
RL mengamuk. RL juga pernah membanting laptop ayahnya saat RL menonton Masha and the Bear di youtobe mengalami masalah jaringan.

Kebiasaan makan RL sejak saat lahir sampai RL diketahui mengalami gangguan spektrum autisme tidak dibatasi oleh orang tuanya. Setelah mengetahui RL mengalami gangguan spektrum autisme, orangtua RL masih membebaskan RL memilih makanan yang diinginkan karena orang tua RL belum memahami kebiasaan makan yang baik untuk anak berganguan tersebut. Menurut orang tua RL sering terlihat hiperaktif.

Setelah orang tua RL melakukan konsultasi dengan dokter tentang kebiasaan makan yang baik untuk anak gangguan spektrum autisme, orang tua RL baru memahami kebiasaan makan yang baik untuk anak gangguan spektrum autisme. Saat itu orang tua RL sempat melarang RL untuk mengosumsi makanan-makanan yang dapat memperburuk gejala seperti gluten, kasein, dan zat aditif. Saat RL tidak memakan makanan yang mengandung gluten, kasein, dan zat aditif RL terlihat lebih tenang dari sebelumnya.

Setelah beberapa waktu orangtua RL menerapkan kebiasaan makan yang baik, orangtua RL akhirnya tidak menerapkan lagi kebiasaan makan tersebut. Menurut orang tua RL mereka merasa kasihan jika melarang anak mereka untuk memakan makanan yang diinginkan sehingga RL kembali memakan makanan yang mengandung gluten, kasein, dan zat aditif. Orang tua memang menyadari ada terjadi perburukan pada gejala RL seperti sering menjadi hiperaktivitas setelah RL kembali memakan makanan-makanan tersebut. Menurut orang tua, RL tinggal di lingkungan padat penduduk yang mengakibatkan RL sering melihat orangorang yang membawa minuman dan makanan yang mengandung gluten, kasein, dan zat aditif. Hal itu membuat RL menjadi sulit diatur soal kebiasaan makan yang baik, karena RL ingin memakan dan meminum apa yang dilihat disekitarnya. Ini membuktikan terjadi perburukan gejala seperti hiperaktif terhadap RL setelah memakan makanan yang mengandung gluten, kasein, dan zat aditif.

Kebiasaan makan RL, pada pagi hari RL sering diberikan nasi putih dan ikan goring. Setelah makan pagi RL sering memakan roti. Pada siang hari RL sering diberikan nasi putih dan ikan, dan setelah makan siang RL sering mengonsumsi snack, soft drink, coklat dan permen. Pada malam hari RL sering diberikan nasi putih dan ikan, dan setelah itu RL terkadang memakan permen.

\section{Kasus kedua}

DR seorang anak laki-laki, usia 12 tahun, beragama Kristen, bertempat tinggal di Liwas, bersekolah di SLB AGCA Center Manado. DR tinggal bersama dengan kedua orang tua dan kakaknya. Ayahnya seorang dokter dan ibunya seorang Pegawai Negeri Sipil. Saat hamil, ibu DR mengalami perdarahan dari jalan lahir seperti haid. Ketika diperiksakan ke dokter, ibu DR dianjurkan untuk segera melakukan pemeriksaan laboratorium jangan sampai janinnya sudah tidak ada di dalam kandungan. Setelah itu, ibu DR merasa sangat lemah sehingga dokter memberikan vitamin selama 4 bulan, setiap hari 1 butir.

DR dilahirkan oleh bidan disebuah klinik. Pada saat lahir, DR tidak mengangis secara spontan karena terlilit tali pusat. DR menangis setelah diberikan rangsangan. Setelah lahir, DR diberikan imunisasi yang lengkap. DR sudah bisa berjalan sejak berumur 10 bulan dan aktif seperti anakanak pada umumnya. Saat DR berusia 2 tahun DR suka bermain dengan cara memanjat lemari. Menurut kakek dan neneknya, hal tersebut wajar untuk anak laki-laki karena saat itu mereka tinggal bersama dengan RL dan orangtuanya; orangtua DR juga berpikir demikian. Pada usia 2 tahun tidak terjadi perkembangan perilaku DR. DR belum bisa mengucapkan kata apapun.

Saat DR berumur 2 tahun DR tinggal bersama orangtuanya di Molompar karena ayahnya bertugas disana. Pada waktu itu disana sedang terjadi musim penyakit 
Onibala, Dundu, Kandou: Kebiasaan makan pada...

cikungunya. Saat tinggal disana DR tibatiba mengalami demam tinggi. Setelah DR mengalami demam tinggi DR menjadi lebih aktif seperti sering berlarian di kamar. Pada waktu DR menderita sakit, DR di bawah orang tuanya ke dokter spesialis anak kemudian ayahnya juga bertanya ke dokter kenapa DR sudah berumur 2 tahun tapi belum bisa berbicara serta perilaku anak yang sangat aktif dan terlihat nakal; menurut dokter, DR menunjukkan gejala gangguan spektrum autisme. Dokter menganjurkan untuk diperiksakan ke bagian psikiatri tetapi ibunya tidak membawanya karena ibunya tidak mau anaknya dianggap mengalami gangguan jiwa.

DR sudah bersekolah selama 9 tahun. Saat bersekolah DR cepat menghafal dan patuh terhadap gurunya. Saat ini DR bisa berbicara, tetapi DR hanya berbicara ketika ditanya. DR biasanya hanya menarik tangan ibunya kemudian menunjuk kearah meja jika DR ingin makan, kemudian ibunya bertanya "DR mau apa?" kemudian DR menjawab "makan”. Cara bicara DR sudah jelas saat DR bersekolah.

Menurut orangtuanya DR mengalami perbaikan perilaku; hal itu dikarenakan orangtua memberikan makan yang baik seperti bebas gluten, kasein,dan zat aditif. Orang tua DR memahami betul kebiasaan makan yang baik untuk anak autisme karena orang tua DR sering berkonsultasi dengan dokter dan sering mencari tahu di internet tentang kebiasaan makan yang baik untuk anak gangguan spektrum autisme, sehingga DR diterapkan kebiasaan makan yang baik seperti bebas gluten, kasein, dan zat aditif. Saat ini DR sudah terlihat tenang dan tidak terjadi perburukan dalam gejala autisme yang dialami. Hal ini membuktikan terdapat pengaruh yang baik terhadap penerapan kebiasaan makan bebas gluten, kasein dan zat aditif. Pola makan ini selalu diterapkan kepada DR.

Kebiasaan makan DR, pada pagi hari DR sering diberikan nasi putih dengan abon cakalang. Pada siang hari DR sering diberikan nasi putih dengan cakalang, setelah itu DR sering diberikan buah. Pada malam hari DR sering diberikan nasi putih dengan ikan.

\section{BAHASAN \\ Bahasan penelitian kuantitatif}

Berdasarkan penelitian yang dilakukan pada 33 responden di Sekolah Luar Biasa Khusus Autis Permata Hati, Sekolah Luar Biasa Khusus Autis Hizkia, Sekolah Luar Biasa AGCA Centre Manado, Sekolah Luar Biasa GMIM Nazareth Tuminting, Sekolah Luar Biasa tipe A Bartemeus, Sekolah Luar Biasa YPAC Manado, Sekolah Luar Biasa Tuna Grahita St. Anna Tomohon, Autisme Centre Manado, dan Sentra Pendidikan Anak Berkebutuhan Khusus Amadeus di Winangun diperoleh $15,2 \%$ anak menerapkan pola makan bebas gluten, 30,1\% anak yang menerapkan pola makan bebas kasein, dan 30,1\% yang menerapkan pola makan bebas zat aditif. Penelitian ini tidak jauh berbeda dengan penelitian yang dilakukan Reissman ${ }^{10}$ dari 11 jurnal ilmiah yang dikumpulkan sampai Desember 2013 di Jerman yang mendapatkan anak dengan pola makan bebas gluten, kasein, dan zat aditif sebanyak $8-32 \% .{ }^{10}$ Minimnya penerapan pola makan bebas gluten, kasein, dan zat aditif ini bisa berhubungan dengan hal-hal berikut: ${ }^{11}$

- Minimnya pendidikan orangtua mengenai pola makan yang baik untuk anak autisme

- Perlawanan dari anak terhadap pemberian makanan

- Orangtua tidak tahu menyiapkan makan yang bebas gluten, kasein, dan zat aditif.

Berdasarkan hasil penelitian, pola makan yang baik pada anak autis sangat bergantung kepada orang tua dalam menyediakan makanan untuk anaknya. Orang-orang di rumah dan lingkungan sekitar juga ikut terlibat dalam menerapkan pola makan yang baik pada anak autis. Seperti penelitian yang dilakukan oleh Sofia, ${ }^{8}$ orang tua dan orang-orang sekitar sangat berperan dalam menerapkan pola makan yang baik untuk anak autis. 


\section{Bahasan penelitian kualitatif}

Pola makan pada anak autis bisanya diterapkan pola makan bebas gluten dan kasein serta menghindari makanan yang mengandung zat aditif. Pola makan tersebut dianggap baik dan dapat membantu mengurangi perburukan gejala anak yang menderita autisme. Oleh karena itu untuk memenuhi pola makan yang baik diperlukan peran orangtua sebagai penentu makanan untuk anak mereka. ${ }^{11}$

\section{Dinamika kasus 1 dan bahasan}

Keluarga RL berasal dari keluarga yang berpendidikan rendah; pendidikan terakhir dari orangtua DR ialah SMA. Ayahnya seorang pedagang dan ibunya seorang ibu rumah tangga, tetapi dirumah mereka membuka warung kecil dan menjual jajanan. Kebiasaan makan RL tidak bisa diatur dan menyebabkan RL memakan makanan yang dijual ibunya padahal makanan tersebut tidak baik untuk perkembangannya. RL sering memakan makanan yang mengandung gluten, kasein, dan zat aditif; akibatnya orangtua melihat sering terjadi perburukan gejala seperti bertambahnya hiperaktivitas dari RL. Orang tua RL merasa kasihan jika tidak memberikan makanan yang diinginkan RL.

Menurut Ritmie dan Fillah, konsumsi gluten, kasein dan zat aditif dapat memperburuk gejala autism. Penelitian mereka membuktikan adanya hubungan bermakna antara frekuensi diet bebas gluten bebas kasein dengan skor perilaku autis. Artinya, semakin tinggi frekuensi konsumsi makanan yang mengandung gluten maupun kasein, maka semakin tinggi skor perilaku autis. ${ }^{4}$

RL tinggal di lingkungan padat penduduk. Hal ini mengakibatkan RL sangat susah menerapkan pola makan yang baik seperti bebas gluten, kasein, dan zat aditif karena RL sering melihat berbagai jenis makanan yang dimakan oleh tetangganya padahal makanan tersebut tidak baik untuk gejala autis. Menurut Sofia, ${ }^{8}$ sangat dibutuhkan keterlibatan orang-orang di rumah dan lingkungan sekitar untuk membantu menerapkan pola makan yang baik untuk anak autis.

\section{Dianamika kasus 2 dan bahasan}

DR berasal dari keluarga yang berkecukupan. Ayahnya seorang dokter dan ibunya seorang pegawai negeri sipil, sehingga semua pola makan yang baik bisa diterapkan. Hal ini dikarenakan orang tua DR memahami pola makan yang baik untuk anak autis, sehingga DR diterapkan pola makan yang tidak mengandung gluten, kasein, dan zat aditif. DR memiliki perkembangan perilaku yang baik, serta tidak terjadi perburukan gejala autisme. Hal tersebut membuat orang tua DR yakin bahwa pola makan bebas gluten, kasein dan zat aditif bermanfaat sehingga pola makan tersebut terus diterapkan sampai sekarang.

Pemberian makanan jenis tertentu dan perubahan pola makan yang tepat untuk anak autis dapat memperbaiki beberapa gejala autisme. Terdapat orangtua yang percaya bahwa anaknya mengalami alergi makanan atau sensitif terhadap komponen makanan sehingga mereka melakukan tes alergi untuk konfirmasi. Walaupun dalam pemeriksaan tidak ditemukan alergi, akan tetapi orangtua tetap memilih untuk menerapkan diet GFCF, dan sebagai hasil mereka melaporkan terdapat perbaikan dalam perilaku dan bicara. ${ }^{12}$ Penelitian yang dilakukan oleh Aritonang ${ }^{9}$ melaporkan bahwa orangtua yang menerapkan diet bebas gluten dan kasein mengatakan terdapat perbaikan perilaku pada anak mereka. Anak menjadi lebih baik, lebih tenang, dapat berinteraksi, dan dapat mengendalikan emosinya dengan baik. Pada saat berada di kelaspun anak dapat berkonsentrasi dan belajar.

\section{Perbandingan antar kedua kasus}

Kasus pertama, RL berasal dari keluarga yang berpendidikan rendah, ayahnya seorang pedagang dan ibunya seorang ibu rumah tangga. Tingkat pengetahuan dapat memengaruhi pengetahuan ibu tentang pola makan yang baik untuk anak dengan gangguan spektrum autisme. RL sering memakan makanan yang mengandung gluten, kasein, 
Onibala, Dundu, Kandou: Kebiasaan makan pada...

dan zat aditif, sehingga terjadi perburukan gejala autism, seperti hiperaktivitas. Hal ini menunjukkan pola makan RL merupakan pola makan yang buruk karena RL sering menjadi lebih hiperaktivitas.

Pada kasus kedua, DR berasal dari keluarga yang berpendidikan. Ayahnya seorang dokter dan ibunya seorang pegawai negeri sipil. DR tidak diberikan makan yang mengandung gluten, kasein, dan zat aditif. Menurut orangtuanya, DR mengalami perbaikan gejala autisnya. Sekarang DR terlihat lebih tenang dan lebih fokus. Hal tersebut mennunjukkan bahwa pola makan yang diterapkan pada DR merupakan pola makan yang baik.

Penerapan pola makan pada anak dengan gangguan spektrum autisme sangat penting karena dapat memperburuk atau memperbaiki gejala autisme. Penelitian yang dilakukan membuktikan bahwa anak dengan penerapan makanan bebas gluten, kasein, dan zat aditif dapat memperbaiki gejala autisme yang dialami sedangkan penerapan makanan yang menggunakan gluten, kasein, dan zat aditif dapat memperburuk gejala autisme seperti hiperaktivitas. ${ }^{5}$

\section{SIMPULAN}

Berdasarkan hasil penelitian yang dilakukan dapat disimpulkan bahwa:

1. Pola makan berperan penting dalam membantu perbaikan gejala autisme

2. Tingkat pengetahuan orangtua tentang pola makan yang baik sangat diperlukan

3. Pola makan yang baik pada anak dengan gangguan spektrum autisme ialah pola makan bebas gluten, kasein, dan zat aditif.

4. Kesalahan penerapan makanan pada anak dengan gangguan spektrum autisme dapat menyebabkan perburukan gejala autisme.

\section{DAFTAR PUSTAKA}

1. Ratajczak HV. Theoretical aspects of autism: Causes-A review. J Immunotoxicol. 2011;8:68.

2. Efendi M, Prasetyo R, Hayu RL.
Gambaran faktor prenatal sebagai penyebab autis di Sekolah Anak Khusus Kembang Mekar Desa Kepanjen Kecamatan Jombang Kabupaten Jombang tahun 2013. Jurnal Metabolisme. 2013;3:2.

3. Noor M, Indriati G, Elita V. Pengalaman ibu dalam merawat anak autism usia sekolah. Program Studi Ilmu Keperawatan Universitas Riau. PSIK Jurnal. 2014;1:1.

4. Setiawan F. Pola penanganan autis di Yayasan Sayab Ibu (YSI) Yogyakarta [Skripsi]. Yogyakarta: Universitas Islam Negeri Sunan Kalijaga; 2010.

5. Pratiwi RA, Dieny FF. Hubungan skor frekuensi diet bebas gluten bebas casein dengan skor perilaku autis. Program Studi Ilmu Gizi Fakultas Kedokteran Universitas Diponegoro. Journal of Nutrition College. 2014;3:34,35.

6. Latifah RE. Studi konsumsi dan status gizi pada anak penyandang gangguan spektrum autisme di Kota Bogor [Tesis]. Bogor: Fakultas Pertanian Institut Pertanian Bogor; 2004.

7. Myles J G, Farmer C, Thurm A, Royster C, Kahn P, Soskey L, et al. Dietary adequacy of children with autism compared to controls and the impact of restricted diet. J Dev Behav Pediatr. 2013;34(7):449-59.

8. Sofia DA, Hj. Ropi H, Mardiyah A. Kepatuhan orang tua dalam menerapkan terapi diet GFCF pada anak penyandang autisme di Yayasan Pelita Hafizh dan SLBN Cileunyi Bandung. Bandung: Fakultas Ilmu Keperawatan Universitas Padjajaran; p. 3-6. Available from: jurnal.unpad.ac.id.

9. Aritonang E, Pardede A, Ervika E. Pengetahuan, sikap dan tindakan ibu dalam pola makan anak penderita autis di Yayasan Tali Kasih. Jurnal Kedokteran Indonesia. Fakultas Psikologi USU. 2009;1:102.

10. Reissman A, Hauser J, Gertruda $\mathbf{E} \mathbf{M}$, Tomsa L, Lange K W. Gluten free and casein free diets in the treatment of autism. Functional Foods in Health and Disease. 2014;4(8):349-61.

11. Kusumayanti GAD. Pentingnya pengaturan makanan bagi anak atis. 
Jurnal e-Clinic (eCl), Volume 4, Nomor 2, Juli-Desember 2016

Jurnal Ilmu Gizi Poltekkes Denpasar.

2011;2:1-8.

Diagnosis \& Penatalaksanaan (1st

12. Kaunang TMD. Gangguan Autisme

ed). Jakarta Pusat: Care Our Children, 2015. 